CLINICAL STUDY

\title{
Thyroid examination in highly radiation-exposed workers after the Chernobyl accident
}

\author{
Bernhard O Boehm ${ }^{1, *}$, Marianna Steinert ${ }^{2, *}$, Johannes W Dietrich ${ }^{1}$, Ralf U Peter ${ }^{3}$, David Belyi ${ }^{4}$, \\ Gerald Wagemaker ${ }^{5}$, Silke Rosinger ${ }^{1}$, Theodor M Fliedner ${ }^{2}$ and Melanie Weiss ${ }^{2}$ \\ ${ }^{1}$ Division of Endocrinology, Department of Internal Medicine and ${ }^{2}$ Radiation Medicine Research Group and WHO-Collaborating Centre for Radiation \\ Accident Management, University of Ulm, D-89081 Ulm, Germany, ${ }^{3}$ Department of Dermatology, Federal Armed Forces Hospital, D-89081 Ulm, \\ Germany, ${ }^{4}$ Scientific Centre of Radiation Medicine, UKA-252050 Kiev, Ukraine and ${ }^{5}$ Institute of Hematology, Erasmus University of Rotterdam, \\ NL-3015 Rotterdam, The Netherlands
}

(Correspondence should be addressed to B O Boehm who is now at Division of Endocrinology and Diabetes, Albert-Einstein-Allee 23, University Medical Centre Ulm, D-89081 Ulm, Germany; Email: bernhard.boehm@uniklinik-ulm.de)

*(B O Boehm and M Steinert contributed equally to this work)

\begin{abstract}
Context: Radioactive contamination from the Chernobyl nuclear accident that happened on the morning of 26th April 1986 had a major impact on thyroid health in the Belarus region. Objective: Observational study of a cohort of 99 adults, most strongly exposed to ionizing radioactivity. Design, setting and patients: Observational study performed between 1998 and 2000. The cohort comprised 99 workers (92 male) of the Chernobyl nuclear power plant. Examination including physical examination, ultrasonography of the thyroid gland and measurement of serum free thyroxin $\left(\mathrm{fT}_{4}\right.$ ), free triiodothyronine ( $\mathrm{fT}_{3}$ ) and TSH. Anti-thyroperoxidase (anti-TPO), antithyroglobulin (anti$\mathrm{Tg}$ ) antibodies and thyroid stimulating immunoglobulin were also determined.

Main outcome measures: The impact of exposure to high-dose radiation, including radioactive iodine, on the thyroid gland was examined.

Results: Levels of $\mathrm{fT}_{4}$ in all probands were within the normal World Health Organization-defined range. Elevated levels of $\mathrm{fT}_{3}$ were found in two workers $(2 \%)$, high titres of anti-TPO and anti-Tg antibodies were present in four subjects (4\%). Mild hypothyroidism was present in one patient. Enlargement of the thyroid gland was observed in 17 workers (17\%). There was no evidence of clinically overt thyroid cancer.

Conclusions: The Chernobyl accident showed surprisingly little impact on the thyroid in a cohort of workers strongly exposed to radiation. Our data suggest an age-dependent heterogeneity in response to the short-lived radioiodine isotopes and favours long-term follow-up analysis.
\end{abstract}

European Journal of Endocrinology 160 625-630

\section{Introduction}

On the 26th of April 1986, reactor 4 at the Chernobyl nuclear power plant severely malfunctioned. The Chernobyl accident is the worst disaster in the history of nuclear power generation. According to recent data, the air at Chernobyl had been contaminated with about $5300 \mathrm{PBq}$ radionuclide activity, including $1760 \mathrm{PBq}$ (131)I and 85 PBq (137)Cs. The highest radiation was received by the liquidators $(0.8-16 \mathrm{~Gy})$, lower doses were received by the population that was evacuated or inhabited the contaminated areas (1-3). The released radioactivity caused a major increase in thyroid cancer in children, and led overall to an almost 100-fold increase in thyroid cancer incidence in the Belarus region (4). These thyroid cancers demonstrated an aggressive phenotype with a high prevalence of lung metastasis (5).
To evaluate the impact of the Chernobyl accident on thyroid health in a unique cohort of power-plant workers and so-called liquidators, a follow-up study (1998-2000) was conducted. These adults were most strongly exposed to the ionizing radioactivity. In this report, we describe results from a cross-sectional evaluation of 99 probands who were among the most severely irradiated employees of the Chernobyl power plant and who were originally suspected to have had acute radiation sickness (ARS).

\section{Patients and methods}

\section{Subjects}

Ninety-nine patients exposed to ionizing radiation from the Chernobyl accident and available for 
follow-up at clinical centres in Kiev, Moscow and Ulm were examined between 1998 and 2000. The cohort comprised 92 male and 7 female patients with a mean age at the time of exposure of 33 years (range 21-60 years) and a mean age at follow-up examination (1998-2000) of 47 years (range 35-74 years).

Twenty-four of 99 (24\%) reported regular oral iodine administration, with a maximal dose of $200 \mu \mathrm{g} /$ day before and after the accident. Blocking of radioiodine uptake by thyroid using potassium iodide (KI) according to International Atomic Energy Agency recommendations (KI prophylaxis) had not been used in this cohort.

These patients were among the most severely exposed to high local doses of $\beta$-particle and $\gamma$ radiation, either as working personnel within the reactor immediately after the accident or as members of the immediate clean-up forces (so-called liquidators) in the days following the accident. Table 3 gives histories of patients with an impairment of the thyroid gland during or immediately after the accident.

The whole-body exposure radiation dose was reported as 0.3-8.7 Gy (2). All patients were classified into four groups based on the severity of ARS in the acute phase after the accident, as previously described (6). Patient characteristics with respect to ARS severity are presented in Table 1. Twenty-two patients in the study cohort suffered from first-degree ARS, 24 from second-degree ARS, 10 from third-degree ARS, and one from fourth-degree ARS. The study cohort also included 42, so-called non-confirmed patients, who were exposed to radiation doses that were not sufficient to induce ARS. The ARS radiation doses received were, however, high enough to cause mild clinical signs and symptoms, including changes in peripheral blood counts. In 1989, a re-evaluation of the so-called nonconfirmed showed that these patients did not in fact have ARS.

\section{Physical examination}

Detailed case histories were obtained and physical examinations were performed in all patients. Thyroid enlargement was determined using inspection and palpation in accordance with the WHO definition of 4 degrees: 0a, no goitre; Ob, palpable but not visible goitre; I, palpable and visible goitre at reclined head position; II, visible goitre.

\section{Ultrasonography}

The thyroid gland was examined using a highresolution linear ultrasonographic $7.5-\mathrm{MHz}$ transducer (Aloka 630, Japan). The volume of the thyroid gland was determined as reported by Brunn and coworkers (7). Subsequently, thyroid gland enlargement, i.e. goitre, was diagnosed when the thyroid gland volume exceeded $25 \mathrm{ml}$ in male or $20 \mathrm{ml}$ in female patients respectively. If present, nodules were classified according to the following features: no/diffuse microcalcifications, regular/irregular margins, regular/irregular sonolucent halo and no/regional lymphadenopathy. No fine-needle biopsies have been performed and no thyroid surgery was performed after the accident.

\section{Lab analysis}

Serum concentrations of $\mathrm{fT}_{4}, \mathrm{fT}_{3}$ and $\mathrm{TSH}$ were measured using highly sensitive immunometric technology (Ortho-Clinical Diagnostics GmbH, Neckargmünd, Germany). Serum levels of anti-thyroperoxidase (anti-TPO) and antithyroglobulin (anti-Tg) antibodies were determined using a commercially available variable ELISA (Vita Diagnostica GmbH, Freiburg, Germany). The ELISA test was considered, according to the criteria of the European Thyroid Association, as detecting anti-TPO in preparations of thyroid microsomes (8). Thyroid stimulating immunoglobulin (TSI) titres were measured using a commercially available

Table 1 Patient characteristics according to acute radiation sickness (ARS) severity.

\begin{tabular}{|c|c|c|c|c|c|c|c|c|}
\hline $\begin{array}{l}\text { ARS } \\
\text { severity }\end{array}$ & $\begin{array}{c}\text { Primary } \\
\text { diagnosis } \\
1986\end{array}$ & $\begin{array}{c}\text { ARS } \\
\text { re-evalua- } \\
\text { tion }^{\mathrm{a}} 1989\end{array}$ & $\begin{array}{l}\text { Deaths in } \\
\text { the acute } \\
\text { period }^{b}\end{array}$ & $\begin{array}{c}\text { Survivors } \\
\text { of the acute } \\
\text { phase }\end{array}$ & $\begin{array}{c}\text { Deaths } \\
1986-2000^{c}\end{array}$ & $\begin{array}{l}\text { Survivors } \\
\text { at the end } \\
\text { of } 2000\end{array}$ & $\begin{array}{l}\text { Number of } \\
\text { examined } \\
\text { patients } \\
1998-2000^{d}\end{array}$ & $\begin{array}{c}\text { Patients } \\
\text { with thyroid } \\
\text { impairment } \\
\text { 1998-2000 }\end{array}$ \\
\hline Non-confirmed & 0 & 103 & 0 & 103 & 6 & 97 & 42 & 5 \\
\hline I mild & 131 & 41 & 0 & 41 & 4 & 37 & 22 & 5 \\
\hline II moderate & 59 & 50 & 1 & 49 & 6 & 43 & 24 & 6 \\
\hline IV very severe & 21 & 21 & 20 & 1 & 0 & 1 & 1 & 1 \\
\hline Total & 237 & 237 & 28 & 209 & 19 & 190 & 99 & 17 \\
\hline
\end{tabular}

${ }^{a}$ ARS was confirmed in 134 cases in 1989 re-evaluations on the basis of clinical symptoms, dynamics of neutrophils, lymphocytes, and thrombocytes in peripheral blood, and chromosomal aberrations of peripheral lymphocytes.

${ }^{b}$ Twenty-eight patients died within a few weeks of the accident, mainly due to local injuries rather than bone marrow failure.

' In the period between the end of 1986 and 2000, 19 patients died from bone marrow failure $(N=12)$; accidents and/or suicide $(N=7)$.

dNinety-nine of the original 237 patients were re-examined between 1998 and 2000. 
luminescence receptor assay (BRAHMS Diagnostica $\mathrm{GmbH}$, Henningsdorf, Germany). Autoantibody titres are presented in units of IU/ml (anti-TPO, anti-Tg) or IU/l (TSI) according to a World Health Organization reference. The normal ranges for these thyroid hormones and thyroid antibodies are: $\mathrm{fT}_{4}, 10-23 \mathrm{nmol} / \mathrm{l} ; \mathrm{fT}_{3}, 1.4$ $2.8 \mathrm{nmol} / \mathrm{l}$; TSH, 0.2-4.2 mIU/l; anti-Tg and anti-TPO, 0-100 IU/ml; TSI, <9 IU/l. Hypothyroidism was defined as $\mathrm{fT}_{4}<10 \mathrm{nmol} / \mathrm{l}$ and $\mathrm{TSH} \geq 3.5 \mathrm{mIU} / \mathrm{l}$. Positive thyroid autoantibodies were defined as antiTOP and anti-TG concentrations $>100 \mathrm{IU} / \mathrm{ml}$ and TSI concentrations $>9 \mathrm{IU} / \mathrm{l}$.

Study probands provided written informed consent for the follow-up study.

\section{Results}

\section{Physical examination}

No clinically apparent signs of thyroid dysfunction were present in the cohort. Various degrees of thyroid gland enlargement were present in 17 of 99 patients. Nine patients had Ob-degree goitre, seven patients had degree-I goitre, and one patient had degree-II goitre (Table 2). No evidence of pressure to adjacent structures, infiltration, lymph-node enlargement or regional or distant metastasis was found on physical examination.

\section{Ultrasonography}

Using ultrasonography, a nodular goitre was diagnosed in 10 and a diffuse goitre in seven of the abovementioned patients respectively (Tables 2 and 3).
All nodules determined were lacking microcalcifications, irregular margins, irregular sonolucent halo and regional lymphadenopathy. Four probands revealed a solitary thyroid nodule, and six probands showed multinodularity. All nodules appeared with a regular margin and/or a well-defined sonolucent halo. No fine-needle biopsies have been performed.

\section{Laboratory examination}

Thyroid hormones could be determined in 74 out of 99 patients. Serum $\mathrm{fT}_{4}$ levels were within the normal range in all cases (mean + s.D. $18 \mathrm{nmol} / \mathrm{l}+2.46$, range $12.4-$ $23.3 \mathrm{nmol} / \mathrm{l}$ ). In one patient, the serum TSH level was slightly above the normal range $(4.49 \mathrm{mIU} / \mathrm{l})$, and $\mathrm{fT}_{4}$ was close to the reference minimum $(11 \mathrm{nmol} / \mathrm{l})$. This male patient had suffered from fourth-degree ARS. In 1986, he was 25 years old; at the time of examination, he was 39 years old. Two patients had elevated serum $\mathrm{fT}_{3}$ levels (2.98 and $\left.4.15 \mathrm{nmol} / \mathrm{l}\right)$. There were, however, no abnormalities in $\mathrm{fT}_{4}$, basal $\mathrm{TSH}$, or thyroid antibodies. Both patients were reported as having suffered second-degree ARS; their age at exposure was 25 years, and their age at examination was 40 years.

\section{Autoantibodies}

In four cases (three males, one female), anti-TPO antibodies were present at a markedly high concentration $(\mathrm{mean}+$ S.D. $1104 \mathrm{IU} / \mathrm{ml}+1275$, range $234-$ $3000 \mathrm{IU} / \mathrm{ml}$ ). Three out of these four patients also had increased anti-TG antibody titres (mean+s.D. $1119 \mathrm{IU} / \mathrm{ml}+1629$, range $202-3000 \mathrm{IU} / \mathrm{ml}$ ). In three of these patients, serum $\mathrm{fT}_{3}, \mathrm{fT}_{4}$ and $\mathrm{TSH}$ concentrations

Table 2 Laboratory findings.

\begin{tabular}{|c|c|c|c|c|c|c|c|c|c|}
\hline \multirow[b]{2}{*}{$\begin{array}{l}\text { Patient } \\
\text { number }\end{array}$} & \multirow[b]{2}{*}{$\begin{array}{l}\text { ARS } \\
\text { severity }\end{array}$} & \multirow{2}{*}{$\begin{array}{l}\text { Age at } \\
\text { examination } \\
\text { (years) }\end{array}$} & \multirow[b]{2}{*}{ Goitre } & \multicolumn{3}{|c|}{ Thyroid hormones } & \multicolumn{3}{|c|}{ Thyroid antibodies } \\
\hline & & & & TSH (MIU/I) & $\mathrm{fT}_{4}(\mathrm{nmol} / \mathrm{l})$ & $\mathrm{fT}_{3}(\mathrm{nmol} / \mathrm{l})$ & $\begin{array}{l}\text { Anti-Tg } \\
\text { (IU/ml) }\end{array}$ & $\begin{array}{l}\text { Anti-TPO } \\
(\mathrm{IU} / \mathrm{ml})\end{array}$ & TSI (IU/I) \\
\hline 1 & n.c. ${ }^{a}$ & 63 & $\mathrm{Ob}$ & 1.47 & 17.6 & 2.05 & 69 & 234 & $<1$ \\
\hline 2 & n.c. & 45 & $0 b$ & 3.1 & 20.4 & 2.65 & 13 & 15 & $<1$ \\
\hline 3 & n.c. & 48 & I & 1.12 & 14.4 & 2.09 & 22 & $<10$ & $<1$ \\
\hline 4 & n.c. & 61 & I & 3.71 & 22.6 & 2.27 & $<10$ & $<10$ & $<1$ \\
\hline 5 & n.c. & 73 & Ob & 2.63 & 15.7 & 2.14 & 33 & $<10$ & $<1$ \\
\hline $6^{b}$ & 1 & 58 & $\mathrm{Ob}$ & 2 & 23 & 2.07 & 202 & 580 & $<1$ \\
\hline 7 & I & 45 & I & 2.32 & 17 & 1.91 & 45 & $<10$ & $<1$ \\
\hline 8 & I & 55 & Ob & 2.12 & 16 & 1.84 & $<10$ & $<10$ & $<1$ \\
\hline 9 & I & 56 & I & 1.35 & 13.3 & 1.8 & $<10$ & $<10$ & $<1$ \\
\hline 10 & I & 70 & Ob & 2.35 & 21.4 & 2.03 & $<10$ & $<10$ & $<1$ \\
\hline 11 & II & 61 & I & 3.56 & 19.2 & 2.04 & 154 & $>3000$ & $<1$ \\
\hline 13 & II & 37 & $\mathrm{Ob}$ & 0.6 & 17.6 & 4.15 & 41 & $<10$ & $<1$ \\
\hline 14 & II & 38 & $\mathrm{Ob}$ & 3.33 & 23.3 & 2.98 & 12 & $<10$ & $<1$ \\
\hline 15 & II & 68 & 1 & 2.95 & 17.7 & 1.94 & 25 & $<10$ & $<1$ \\
\hline 16 & II & 52 & II & 2.18 & 20.2 & 2.18 & 17 & $<10$ & $<1$ \\
\hline 17 & IV & 40 & Ob & 4.49 & 11 & 1.36 & 13 & 11 & $<1$ \\
\hline
\end{tabular}

${ }^{a}$ Non-confirmed patient.

${ }^{\mathrm{b}}$ Female patient. 
Table 3 History of patients with structural or functional thyroid abnormalities.

\begin{tabular}{|c|c|}
\hline Patient number & History \\
\hline 1 & Worked as watchman on the night of the accident ${ }^{\mathrm{a}}$ and stayed $150 \mathrm{~m}$ from the reactor area for $15 \mathrm{~min}$ \\
\hline 2 & Worked as a fireman for $\sim 4 \mathrm{~h}$ on the night of the accident \\
\hline 3 & $\begin{array}{l}\text { On the night of the accident worked } 1400-1500 \mathrm{~m} \text { from the explosion area in block IV, stayed there until } 0500 \mathrm{~h} \text {, and } \\
\text { during the following hour was located } 300-400 \mathrm{~m} \text { from the explosion area. On April } 26 \text { at } 0600 \mathrm{~h} \text { experienced } \\
\text { headache and nausea and vomited several times }\end{array}$ \\
\hline 4 & Worked as a watchman and spent $8 \mathrm{~h}$ walking $\sim 20-30 \mathrm{~m}$ around the reactor on the night of the accident \\
\hline 5 & Worked as a member of the liquidator team immediately after the accident \\
\hline 6 & $\begin{array}{l}\text { Worked on the night of the accident and spent } 10 \mathrm{~min} 50-100 \mathrm{~m} \text { from the explosion area in block IV. On April } 26 \text { at } \\
1600 \mathrm{~h} \text {, experienced nausea and vomited } 10 \text { times. Patient was transferred to Hospital Number } 6 \text { in Moscow } 1 \text { day } \\
\text { after the accident }\end{array}$ \\
\hline 7 & $\begin{array}{l}\text { Worked at the reactor for } 2.5 \mathrm{~h} \text { on the night of the accident. Immediately after the accident, the patient took } 200 \mu \mathrm{g} \\
\text { potassium iodide and put on a gas mask. On April } 26 \text { at } 0600 \mathrm{~h} \text { experienced nausea and vomited } 3 \text { times. Patient was } \\
\text { transferred to Hospital Number } 6 \text { in Moscow } 1 \text { day after the accident }\end{array}$ \\
\hline 8 & $\begin{array}{l}\text { Employee at the Chernobyl power plant since 1977. Arrived at the power plant on April } 26 \text { at } 0400 \mathrm{~h} \text { and stayed until } \\
1400 \mathrm{~h} \text {. On April 30, experienced nausea and was hospitalized at Kiev Region Hospital }\end{array}$ \\
\hline 9 & Worked as a member of the liquidator team for $\sim 5 \mathrm{~h}$ on April 26 \\
\hline 10 & On April 26 worked for $4 \mathrm{~h}$ in block IV, $150 \mathrm{~m}$ from the explosion area \\
\hline 11 & $\begin{array}{l}\text { Arrived at the reactor site } \sim 5 \mathrm{~h} \text { after the explosion, took } 200 \mu \mathrm{g} \text { potassium iodide at the entrance gate, and received a } \\
\text { protective mask. Spent } \sim 2 \mathrm{~h} 30-40 \mathrm{~m} \text { from the explosion area. At } 1230 \mathrm{~h} \text { experienced nausea and vomited several } \\
\text { times. Was transferred to Hospital Number } 6 \text { in Moscow } 1 \text { day after the accident }\end{array}$ \\
\hline 12 & $\begin{array}{l}\text { Arrived at the power plant } \sim 3 \mathrm{~h} \text { after the explosion and spent } 30 \mathrm{~min} \text { in block IV, } 300 \mathrm{~m} \text { from the explosion area. On } \\
\text { April } 26 \text { at } 1330 \mathrm{~h} \text { experienced nausea, general fatigue, and headache and vomited more than } 10 \text { times }\end{array}$ \\
\hline 13 & $\begin{array}{l}\text { On April } 26 \text { between } 0800 \mathrm{~h} \text { and } 0900 \mathrm{~h} \text { worked in the power plant } 300 \mathrm{~m} \text { from the reactor. At } 1000 \mathrm{~h} \text { experienced } \\
\text { headache and nausea and vomited four times. Was transferred to Hospital Number } 6 \text { in Moscow } 1 \text { day after the } \\
\text { accident }\end{array}$ \\
\hline 14 & $\begin{array}{l}\text { Worked as a technician at the reactor on the night of the accident. Arrived on April } 26 \text { at } 0245 \mathrm{~h} \text { and spent } \sim 5 \mathrm{~h} 200- \\
300 \mathrm{~m} \text { from the explosion area. Wore protective overalls }\end{array}$ \\
\hline 15 & $\begin{array}{l}\text { Employee at the Chernobyl power plant since } 1976 \text {. On the night of the accident was working as a senior engineer in } \\
\text { technical supervision. On April } 26 \text {, arrived at the reactor at } 0200 \mathrm{~h} \text { and stayed for } \sim 15 \mathrm{~h} \text {. Visited different rooms and } \\
\text { points of the reactor. On April } 26 \text { at } 0300 \mathrm{~h} \text { experienced nausea. Was transferred to Hospital Number } 6 \text { in Moscow } \\
1 \text { day after the accident }\end{array}$ \\
\hline 16 & $\begin{array}{l}\text { Employee at the Chernobyl power plant since } 1977 \text {. On the night of the accident worked as watchman at blocks } V \text { and } \\
\text { VI. On April } 26 \text { at } 0500 \mathrm{~h} \text { arrived at the builder's temporary office, } 400 \mathrm{~m} \text { from block IV. At } 0800 \mathrm{~h} \text { experienced nausea, } \\
\text { and at } 0900 \mathrm{~h} \text { vomited six times. Transferred to Hospital Number } 6 \text { in Moscow } 1 \text { day after the accident }\end{array}$ \\
\hline 17 & $\begin{array}{l}\text { On the night of the accident worked in block IV } 100 \mathrm{~m} \text { from the reactor. Became severely contaminated by sitting on } \\
\text { contaminated pipes. Changed clothes for the first time } 3.5 \mathrm{~h} \text { after the accident. Transferred to hospital Number } 6 \text { in } \\
\text { Moscow } 1 \text { day after the accident. Received bone marrow transplantation }\end{array}$ \\
\hline
\end{tabular}

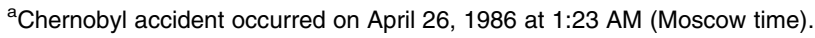

were within the normal range, whereas in one patient TSH was elevated to $9.4 \mathrm{mIU} / \mathrm{l}$ without corresponding changes in $\mathrm{fT}_{3}$ and $\mathrm{fT}_{4}$ levels. Thyroid antibodies in the antibody-positive patients were associated with clinically and sonographically observed goitre. In the antibody-positive patients, mean thyroid gland volume was $33 \mathrm{ml}$ (range $28-40 \mathrm{ml}$ ) in males and $25 \mathrm{ml}$ in the female patient. At the time of exposure, the mean age for all four patients was 47, and was 62 years at examination. Of these patients, two had suffered from second-degree ARS, one from first-degree ARS and one belonged to the non-confirmed group (Table 2 and 3).

\section{Discussion}

Twelve to fourteen years after the Chernobyl accident, we studied a cohort of adults who were exposed to particularly high levels of ionizing radioactivity, including a high dose of radioactive iodine (131-I, 132-I, 133-I and 135-I). This unique cohort comprised 99 long-term survivors from a group of 237 Chernobyl workers including also liquidators originally diagnosed with ARS. By contrast to what has been reported for children from the Belarus area, the impact of the Chernobyl accident on the thyroid condition in this adult cohort was found to be different. No clinically overt thyroid cancer was found.

It is well known that exposure to ionize radiation is associated with an increase in incidence of thyroid abnormalities and in particular thyroid cancer (9-13). An increase in the incidence of thyroid cancer was observed in survivors of the atomic bomb in Japan (14) and in residents of the Marshall Islands exposed to ionize radiation during the testing of hydrogen bombs (15). Of note is the higher rate of thyroid cancer in females. The cohort addressed in our study mostly comprised men therefore reducing the likelihood of thyroid cancer per se.

In Belarus, Russia, and the Ukraine there was a marked increase in the incidence of paediatric thyroid cancer following the Chernobyl accident (16-19). Previous studies demonstrated a higher prevalence of nodular goitre in atomic bomb survivors as compared 
with individuals in control groups $(20,21)$. In our cohort, nodular goitre was present in only $10 \%$. Based on the physical examination and ultrasonography thyroid nodules observed were classified as most likely benign lesions. However, there are no ultrasound characteristics that definitively exclude carcinoma. Since fine-needle biopsies or thyroid surgery had not been performed, we can not rule out the presence of thyroid cancer.

In adults, unlike in children, other radiation-induced pathologies of the thyroid gland such as autoimmune thyroiditis may become more prevalent. In atomic bomb survivors and patients treated with external radiation for non-thyroid diseases, exposure to radiation was associated with increased incidence of thyroid autoimmunity (22-24). In our study, we also found evidence of thyroid autoimmunity. Affected patients reported pain over the thyroid gland, which suggests antibody formation due to acute radiation thyroiditis $(25,26)$. However, it is important to acknowledge that thyroid autoimmunity has also been described in healthy individuals with no documented exposure to ionizing radiation. In two population-based studies from the United Kingdom (Wickham Study) and Australia (Busselton Health Survey) anti-TPO prevalence rates of $6.8 \%$ and $6.6 \%$ respectively, were reported $(28,29)$. In a more recent study using the same antibody detection technology as in this study, $5.1 \%$ of Caucasian healthy blood donors were anti-TPO positive (30).

A limitation of the study is that it is an observational study with no control group. In addition, the number of probands is low when compared with standard population-based evaluations. Therefore, only observational data of a very unique group of patients can be presented. Long-term follow-up including fine-needle aspiration of thyroid nodules will be needed to define the cancer risk more accurately. In view of previous observations of thyroid malignancy in radiationexposed patients, there is still a high probability of subsequent development of thyroid malignancies. Therefore, in accordance with published data, and due to the high susceptibility of the thyroid gland to radiation damage, a detailed long-term follow-up of thyroid function during the next several decades would be of great importance in identifying thyroid malignancies and deviation of its function. Our data, however, do suggest that the pathobiology of the thyroid gland after radiation exposure is different in adults versus children $(30,31)$.

\section{Declaration of interest}

The authors declare that there is no conflict of interest that could be perceived as prejudicing the impartiality of the research reported.

\section{Funding}

Patients were examined as part of projects supported by the Nuclear Fission Safety Programme of the European Commission, the German
Federal Government (Ministry of Health and Ministry of Environment), Research Training Group 'Molecular Diabetology and Endocrinology in Medicine', GRK 1041, Clinical Research Unit, DFG - KliFo 120, and Center of Excellence Baden Wuerttemberg 'Metabolic disorders'.

\section{Acknowledgements}

We thank Drs Ulrich Loos, Natalia Nadejina, Jrina Galstian, Oleg Gergel and Vladimir Bebeshko for their contributions and insightful discussions.

\section{References}

1 Bleuer JP, Averkin YI \& Abelin T. Chernobyl-related thyroid cancer: what evidence for role of short-lived iodines? Environmental Health Perspectives 1997105 1483-1486.

2 Robbins J, Dunn JT, Bouville A, Kravchenko VI, Lubin J, Petrenko S, Sullivan KM, Vanmiddlesworth L \& Wolff J. Iodine nutrition and the risk from radioactive iodine: a workshop report in the Chernobyl long-term follow-up study. Thyroid 200111 487-491.

3 Leoniak M. Zonenberg A \& Zarzycki W. The radiological situation before and after Chernobyl disaster. Endokrynologia Polska 200657 $45-52$.

4 Figge J, Jennings T \& Gerasimov G. Radiation \& thyroid cancer. In Thyroid Cancer: a Comprehensive Guide to Clinical Management, pp 77-116. Ed. L Wartofsky, Totowa New Jersey: Humana Press, 2000 .

5 Pacini F, Vorontsova T, Demidchik EP, Molinaro E, Agate L, Romei C, Shavrova E, Cherstvoy ED, Ivashkevitch Y, Kuchinskaya E, Schlumberger M, Ronga G, Filesi M \& Pinchera A. Post-Chernobyl thyroid carcinoma in Belarus children and adolescents: comparison with naturally occurring thyroid carcinoma in Italy and France. Journal of Clinical Endocrinology and Metabolism $1997 \mathbf{8 2}$ 3563-3569.

6 Barabanova A \& Guskova AK. The diagnosis and treatment of skin injuries and other non-bone-marrow syndromes in Chernobyl victims. In The Medical Basis for Radiation Accident Preparedness. II Clinical Experience and Follow-up, pp 183-189. Eds RC Ricks \& SA Fry, New York: Elsevier, 1990.

7 Brunn J, Block U, Ruf G, Bos I, Kunze WP \& Scriba PC. Volumetrie der Schilddrüsenlappen mittels Real-time-Sonographie. Deutsche Medizinische Wochenschrift 1981106 1338-1340.

8 McLachlan SM, Furmaniak J, Fenzi GC, Orgiassi J, Carajon P \& Mariotti S. Nomenclature of thyroid autoantibodies. European Thyroid Association 1989.

9 Baverstock K, Egloff B, Pinchera A, Ruchti C \& Williams D. Thyroid cancer after Chernobyl. Nature 1992359 21-22.

10 Kasakov VS, Demidchik EP \& Astakhova LN. Thyroid cancer after Chernobyl. Nature 19923921.

11 Likhtarev IA, Sobolev BG, Kairo IA, Tronko ND, Bogdanova TI, Oleinik VA, Epshtein EV \& Beral V. Thyroid cancer in the Ukraine. Nature 1995375365.

12 Williams ED, Pacini F \& Pinchera A. Thyroid cancer following Chernobyl. Journal of Endocrinological Investigation $1995 \mathbf{1 8}$ 144-146.

13 Ron E, Lubin JH, Shore RE, Mabuchi K, Modan B, Pottern LM, Schneider AB, Tucker MA \& Boice JD. Thyroid cancer after exposure to external radiation: a pooled analysis of seven studies. Radiation Research 1995141 259-277.

14 Sampson RJ, Key CR, Buncher CR \& Iijima S. Thyroid carcinoma in Hiroshima and Nagasaki. Journal of the American Medical Association 1969209 65-70.

15 Conard RA, Peglia DE, Larson PR, Sutow WW, Dobyns BM, Robbins J, Krotosky WA, Field JB, Rall JE \& Wolff J. Review of medical findings in Marshallese population twenty-six years after accidental exposure to radio-active fallout. Brookhaven National Laboratory $1980 \mathbf{5 1 2 6 1}$ NTIS; 1-138. 
16 Demidchik EP, Drobyshevskaya IM \& Cherstvoy ED. Thyroid cancer in children in Belarus. In The Radiological Consequences of the Chernobyl Accident, pp 677-682. Eds A Karaoglou, G Desmet, GN Kelly \& HG Menzel, Luxembourg: ECSC-EC-EAEC, 1996.

17 Sobolev B, Likhtarev I, Kaito I, Tronko N, Oleynik V \& Bogdanova T. Radiation risk assessment of the thyroid cancer in Ukrainian children exposed due to Chernobyl. In The Radiological Consequences of the Chernobyl Accident, pp 741-748. Eds Karaoglou A, Desmet G, Kelly GN \& Menzel HG. Report No. EUR 16544 EN, Luxembourg: Official Publications of European Communities, 1996.

18 Rybakov SJ, Komissarenko IV, Tronko ND, Kvachenyuk AN, Bogdanova TI, Kovalenko AE \& Bolgov MY. Thyroid cancer in children of Ukraine after the Chernobyl accident. World Journal of Surgery 200024 1446-1449.

19 Williams D, Pinchera A, Karaoglou A \& Chadwick KH. In Thyroid Cancer in Children Living Near Chernobyl, pp 1-108. Eds Karaoglou A, Desmet G, Kelly GN \& Menzel HG. Report No. EUR 15248 EN, Luxembourg: Official Publications of the European Communities, 1993.

20 Morimoto I, Joshimoto Y, Sato K, Hamilton HB, Kawamoto S, Izumi M \& Nagataki S. Serum TSH, thyroglobulin and thyroidal disorders in atomic bomb survivors exposed in youth: 30 years follow-up study. Journal of Nuclear Medicine $1987 \mathbf{2 8} 1115-1122$.

21 Nagataki S, Hirayu H, Izumi M, Inoue S, Okajima S \& Shimaoka K. High prevalence of thyroid nodule in area of radioactive fallout. Lancet 1989 II 385-386.

22 Nagataki S, Shibata Y, Inoue S, Yokoyama N, Izumi M \& Shimaoka K. Thyroid disease among atomic bomb survivors in Nagasaki. Journal of the American Medical Association 1994272 364-370.

23 Hancock SL, Cox RS \& McDougall IR. Thyroid disease after treatment of Hodgkin's disease. New England Journal of Medicine 1991325 599-605.
24 Akiyama M. Late effects of radiation on the human immune system: an overview of immune response among the atomic bomb survivors. International Journal of Radiation Biology 199568 497-508.

25 Dayan CM \& Daniels GH. Chronic autoimmune thyroiditis. New England Journal of Medicine 1996335 97-99.

26 Reinhardt W, Luster M, Rudorff KH, Heckmann C, Petrasch S, Lederbogen S, Haase R, Saller B \& Mann K. Effect of small doses of iodine on thyroid function in patients with Hashimoto's thyroiditis residing in an area of mild iodine deficiency. European Journal of Endocrinology 1998139 23-28.

27 Hawkins BR, Cheuh PS, Dawkins RL, Wittingham S, Burger HG, Patel Y, MacKay IR \& Welborn TA. Diagnostic significance of thyroid microsomal antibodies in randomly selected population. Lancet 1980 II 1057-1059.

28 Tunbridge WMG, Evered DC, Hall R, Appleton D, Brewis M, Clark F, Grimley-Evans J, Young E, Bird T \& Smith PA. The spectrum of thyroid disease in a community: the Wickham survey. Clinical Endocrinology 1977 781-493.

29 Boehm BO, Kühnl P, Lölinger C, Ketzler-Sasse U, Holzberger G, Seidl S, Bäuerle R, Schifferdecker E \& Usadel KH. HLA-DR3 and HLA-DR5 confer risk for autoantibody positivity against the thyroperoxidase (mic-TPO) antigen in healthy blood donors. Clinical Investigator $199371221-225$.

30 Gerasimov G. Update on IDD in the former USSR. IDD Newsletter $1993943-48$.

31 Baverstock K, Egloff B, Pinchera A, Ruchti C \& Williams D. Thyroid cancer after Chernobyl. Nature 1992359 21-22.

Received 3 December 2008

Accepted 7 January 2009 